December 2010

\title{
The Armenian Genocide of 1915 from a Neutral Small State's Perspective: Sweden
}

Vahagn Avedian

Follow this and additional works at: https://digitalcommons.usf.edu/gsp

\section{Recommended Citation}

Avedian, Vahagn (2010) "The Armenian Genocide of 1915 from a Neutral Small State's Perspective: Sweden," Genocide Studies and Prevention: An International Journal: Vol. 5: Iss. 3: Article 8.

Available at: https://digitalcommons.usf.edu/gsp/vol5/iss3/8

This Articles is brought to you for free and open access by the Open Access Journals at Digital Commons @ University of South Florida. It has been accepted for inclusion in Genocide Studies and Prevention: An International Journal by an authorized editor of Digital Commons @ University of South Florida. For more information, please contact digitalcommons@usf.edu. 


\title{
The Armenian Genocide of 1915 from a Neutral Small State's Perspective: Sweden ${ }^{1}$
}

\author{
Vahagn Avedian \\ Chief Editor, Armenica.org
}

\begin{abstract}
This study depicts how the Armenian massacres in the Ottoman Empire during World War I were perceived by a neutral small state, namely, Sweden. The Swedish knowledge should be of special interest since, as a neutral state during the entire conflict, Sweden had no immediate involvement or interest in the ongoing conflict; thus, any reporting about the events would have been untainted compared to that of the Entente or Turkey's allies. The information at hand is also essential to an understanding of the subsequent Swedish reaction. However, surveying the full amount of information needed for comprehensively understanding and analyzing the response to the massacres is beyond the scope of this article and requires a larger study. This article, therefore, addresses the first part, namely charting the information at hand, while the analysis of the response, especially a neutral small state's during an ongoing global conflict, will be left to future studies. The surveyed information in this study shows that information about the Armenian massacres in the Ottoman Empire was abundant.
\end{abstract}

Key words: Armenian Genocide, Sweden, neutral small state

"And look what it says here. The first who were called wogs [svartskallar] were Armenian beggars. They were thrown out from Sweden since it was forbidden to beg." 2 The beggars in question were Armenian survivors from the massacres in the Ottoman Empire.

Today, the Republic of Turkey dismisses almost every historic document presented by the Entente powers of World War I as war propaganda, which they see as serving the sole purpose of defaming Turkey. Turkish documents on the subject, on the other hand, are dismissed by genocide scholars as unreliable, since they are the Turkish government's falsification and a cover-up. ${ }^{3}$ Having said that, it should be mentioned that research on German and Austrian documents, allies of Turkey during the Great War, confirms the Entente's version, rather than that of Turkey. ${ }^{4}$ A neutral nation's observations of the event, however, should be free of any allegations of bias from either side in the conflict. One such nation was the USA, which remained neutral in the conflict until April 1917. The reports and observations made by the US Embassy and American missionaries and relief workers throughout Turkey constitute an important part of the data about the Armenian massacres, since the Americans were the only major power (except Germany and Austria) left inside Turkey after the outbreak of the war. Their presence in Turkey, as well as their neutrality, ended in April 1917 when USA entered the war on the Entente's side. Sweden, on the other hand, remained neutral during the entire conflict and its reports and subsequent actions cannot be ascribed to Swedish involvement in a specific war camp. The full scope of such a study would be to find out how much Sweden knew about the massacres, what alternative actions could have been taken,

Vahagn Avedian, "The Armenian Genocide of 1915 from a Neutral Small State's Perspective: Sweden," Genocide Studies and Prevention 5, 3 (December 2010): 323-340. (C) 2010 Genocide Studies and Prevention. doi:10.3138/gsp.5.3.323 
what alternatives Sweden chose, and why. However, in order to conduct this study within the given limitations, this article will concentrate on the contents of the reports and the information and the analysis that reached Sweden in regard to the Armenian massacres and the fate of Armenia, leaving the three subsequent questions to future studies.

\section{The Swedish Press, Christian Missions, Military Missions, and Embassy Reports}

During World War I, the Swedish press dedicated much space to the war efforts, as did the press in other countries. Among others, a special bureau was created to provide the Swedish countryside papers with articles from the German press. "About fifty papers were among the receivers, mostly conservative publications organs, but also a number of liberal papers." 5 The fact that such a large number of newspapers were under German influence should have affected the reporting of events on Turkey. In order to further influence Swedish opinion, Germany secretly purchased the majority of the shares in the newspapers Aftonbladet and Dagen. With a total circulation of 92,000 , these newspapers equaled the circulation of the Ententefriendly Dagens Nyheter and Social-Demokraten. ${ }^{6}$ This could explain why the news of the massacres in Armenia was a relatively small event in the reports from the front. The resources of the Swedish newspapers were not adequate to employ foreign correspondents of their own. This meant that much of the news concerning foreign affairs was acquired from foreign news agencies, often coloring the perspective of the reports. However, until Hitler's seizure of power in Germany, the leading Swedish publications' foreign policy aimed less at influencing public opinion and more toward debating and providing orientation concerning prevailing international affairs. $^{7}$

While the information published by the newspapers was "second-hand intelligence" acquired from foreign news agencies, there were more reliable information sources documented by individuals present in Turkey. These documents were the reports and dispatches by Swedish missionaries in Turkey and the Caucasus, the Swedish Ambassador to Turkey, and the Swedish Military Attaché in Constantinople. These documents are mainly found in the National Archives, but some are published as memoirs as well.

The material belonging to the Swedish missionaries has been collected from several sources: pamphlets, brochures, and books published during the period of 1915-1923; as well as memoirs published later, which contain eyewitness accounts and stories of the studied period; letters and reports from the missionaries in the field that were sent to the Swedish Church reporting about the status of the missions, as well as depicting the situation in their parish. These documents were found in the Missionary Archive administered partly by the Church of Sweden and partly by the Swedish National Archives.

The reports and the warnings issued by the Swedish missionaries in Turkey and the Caucasus date to the end of the nineteenth century and to the massacres of 1894-1896. ${ }^{8}$ Searching through the missionary correspondence for the period 19141917 did not, however, reveal any special information. An examination of the letters showed that the volume, especially from Turkey, decreased dramatically, with the engagement in the Great War. Stationed in Mush, Western Armenia, beginning in 1910, Alma Johansson, for example, wrote about two to three letters a month to Sweden. During the entire period of 1914-1917, however, there were only four 
letters from her in the archives. ${ }^{9}$ The archivist at Svenska Missionskyrkan (the Mission Covenant Church of Sweden), Katarina Thurell, explained that the lack of information from missionaries all over Europe during World War I was a common phenomenon. The reasons were many: the war forced many missionaries to leave their field missions, and at the same time resulted in communication difficulties; scarce information was also due to wartime censorship and control of the information flow. Letters from missionaries had to pass through military channels. This censorship resulted in letters arriving several months, or longer, after they had been written. Some may never have reached their destination. While it is true that German and Austrian missionaries remained in the area until the end of the war, the censorship by the German and Austrian governments, in regard to the ongoing war effort in general and the reputation of the Turkish ally in particular, strictly prohibited any publication of the information and observations the missionaries relayed back home.

Two larger publications in the form of booklets were Blod och tårar: Armeniernas lidanden $i$ Turkiet ("Blood and Tears: The Sufferings of Armenians in Turkey") and Vad en tysk lektor $i$ asiatiska Turkiet upplevde $i 1915$ ("What a German Senior Lecturer in Asian Turkey Experienced during 1915"). The first is a collection of testimonies, letters, and articles from different medical personnel, missionaries, soldiers, and Armenian survivors about the massacres in the Ottoman Empire, and not all the sources provide first-hand information. The second booklet depicts the experiences of Dr. Martin Niepage, an upper-grade teacher in the German Technical School at Aleppo. His article concentrates mainly on information that should be regarded as more reliable, as it excludes much information attained by hearsay. Both booklets' contents give an interesting insight into the events, both as firsthand testimonies as well as analysis of how the massacres were perceived. In addition, there are some other non-Swedish witness accounts, translated and published in Sweden, that are included in the present study.

The Swedish missionary reports, letters, and pamphlets were yet another means of affecting public opinion, mainly by initiating and persuading the civilian Swedes to contribute to humanitarian aid and collections for the benefit of the victims and survivors of the Armenian massacres. However, they could also indicate the Swedish Church's knowledge of events and its choice of action regarding the massacres, as well as the actions of the missionaries in Western Armenia.

Moving further up the "reliability scale" of the reports and their impact on the Swedish state's knowledge of and basis for decision making are the Swedish military personnel's reports. The most frequently cited Swedish military testimony, used by deniers of the Armenian genocide, is that of Major Gustav Hjalmar Pravitz. He was actually stationed in Persia, not in the Ottoman Empire. Pravitz was a member of the Swedish military mission invited to improve Persia's gendarmerie and police operations. ${ }^{10}$ In 1918, Pravitz published his memoirs, Från Persien $i$ stiltje och storm ("From Persia in Calm and Storm"); however, he published one passage of the book a year earlier in Nya Dagligt Allehanda (NDA), ${ }^{11}$ where he made an interesting assertion: "I guess generally, one can say that a continuous, even if somewhat milder, persecution is less bearable to endure than a bloody but quick act of despotism, as in assaults of the kind that from time to time put Europe's attention on the Armenian question." 12 During his journey through Turkey to reach Persia, Pravitz admitted that he had seen dead bodies and dying people begging for a piece of bread, but, with the exception of one case, he did not see the alleged violence used against the Armenian "emigrants." $13 \mathrm{He}$ also mentions meeting an Armenian in a 
concentration camp ("koncentrationsläger"), itself an interesting choice of word in the context of this study. ${ }^{14}$ In order to be able to put Pravitz's observations and interpretation of the Armenian situation in perspective, it is necessary to also reflect upon his personal view about the Armenian people. In his book, Pravitz renders his views regarding Persia, Persians, and the minorities living in the country. A large portion of the first part of chapter ten, entitled "My Second Journey to Persia," in which he describes the "Armenian question," has more or less the same content as his article in Nya Dagligt Allehanda. Moreover, his description of the Armenian element is not flattering. Jews and Armenians are described as "lying merchants" and Armenians as "highly untrustworthy." 15 In general, he writes that the "bloody" measures of the Turkish government toward the "disloyal" Armenians were quite justified, even though innocent people had suffered too. ${ }^{16}$ The parallels to the argumentation about the Holocaust are too striking to be ignored.

Notwithstanding, the study of the Swedish War Archive reveals another, quite opposite, perspective, expressed by someone much closer to the events, namely, that of Captain Einar af Wirsén (later Major), the official Swedish Military Attaché in Constantinople, 1915-1920.17 In his memoirs, Minnen från fred och krig ("Memories from Peace and War"), published in 1942, referring to Talaat's somewhat gruesome humor, he mentions the following answer Talaat gave him in regard to the Armenian massacres: "I see in the Times that we would have executed, or in other ways killed none less than 800,000 Armenians. I assure you that this is untrue, it was only 600,000."18 Djemal Pasha, however, was more moderate and "disliked the massacres of the Armenians." 19 The book is based upon Wirsén's experiences and memoirs during his service as military attaché in the Balkans and Turkey. Here he demonstrated in more detail his knowledge of the Armenian genocide. Although published in 1942, the book gives insight into how the events were understood by the official Swedish Military Attaché in Turkey when they happened. In the chapter Mordet på en nation ("The Murder of a Nation"), Wirsén gives a brief review of the background to the Armenian question, before describing the atrocities committed by the Turkish government during the war. ${ }^{20} \mathrm{He}$ found the accusations of Armenian collaboration with the Russians questionable. ${ }^{21}$ The subsequent deportations were nothing but a cover for the extermination: "Officially, these had the goal of moving the entire Armenian population to the steppe regions of Northern Mesopotamia and Syria, but in reality they aimed to exterminate [utrota] the Armenians, whereby the pure Turkish element in Asia Minor would achieve a dominating position." 22 Wirsén points out that the orders were given with utter cunning. The communications were generally given verbally and in extreme secrecy in order to give the government a free hand in the implementation of the massacres. ${ }^{23}$ Describing the methods used for massacring the Armenians and depriving the survivors of basic needs so they would perish by hunger and disease, Wirsén notes that the "annihilation of the Armenian nation in Asia Minor must revolt all human feelings ... The way the Armenian problem was solved was hair-raising. I can still see in front of me Talaat's cynical expression, when he emphasized that the Armenian question was solved."24

The military reports are of great importance, since the Swedish Military Attaché, as a representative of a neutral state, was allowed to visit the fronts and gather information about the ongoing campaigns and actions in the Ottoman Empire. He received military intelligence reports, dispatched not only by the Turks but also by the Germans and Austrians serving in the Ottoman Army. The reports show that Wirsén took the liberty to make recommendations about certain actions toward both 
Turkey and Germany, which suggests that his analytic reports were of importance to Swedish foreign policy making.

On 30 April 1915, Sweden's Ambassador to Constantinople, Per Gustaf August Cosswa Anckarsvärd, wrote a five-page dispatch on the subject of the armeniska frägan (Armenian question) and the Armenian revolutionary movement. Noting that the "ghost of the so-called Armenian question" had re-appeared in the interior parts of the country, Anckarsvärd gave a rather detailed chronological description of the issue. ${ }^{25}$ Anckarsvärd mentions that the Sublime Porte, ${ }^{26}$ based upon intelligence information about revolutionary plans, made a mass arrest of about 400 Armenians in Constantinople and numerous others had been taken into custody in other cities as well. "Among the arrested are many Armenian journalists, doctors, and lawyers especially. They had been sent to Angora [Ankara], awaiting trial in a court martial." 27 Anckarsvärd was referring to the arrest of the Armenian intellectuals throughout the Empire, especially in Constantinople.

On 26 May 1915, Svenska Morgonbladet (SvM) published the following telegram from Paris: "Since about a month ago, the Kurdish and Turkish populations in Armenia, in accord with each other and with help from the Turkish Government, have committed mass murder on Armenians. These have occurred from mid-April [new style], in Erzurum, Dertsjun [Ter-Djan], Egin, Bitlis, Mush, Sasun, and others." 28 On 6 July 1915 Anckarsvärd dispatched a two-page report entitled "The Armenian Persecutions," a wording used in the title of six other reports during 1915. The dispatch reads as follows:

The persecutions of the Armenians have reached hair-raising proportions and it all points to the fact that the Young Turks want to seize the opportunity, since there is no effective external pressure to be feared for various reasons, to once and for all put an end to the Armenian question. The means for this are quite simple and consist of the extermination [utrotandet] of the Armenian nation ... It does not seem to be the Turkish population that acts on its own accord, but the entire movement originates in the government institutions and the Young Turks' Committee, which stands behind the government and now displays the kinds of ideas they harbor ... The German Ambassador has in writing appealed to the Porte, but what can Germany or any other of the Major Powers do as long as the war continues? That the Central Powers would threaten Turkey is for the time being unthinkable, and Turkey is already at war with the majority of the remaining Major Powers. ${ }^{29}$

Here, for the first time, Anckarsvärd pinpoints two important observations: (1) the mass killings were state orchestrated, with the Committee of Union and Progress ${ }^{30}$ behind the scene, and (2) their aim was to "exterminate the Armenian nation." The atrocities would justify yet another European intervention, but only once the war was over. The Swedish Ambassador's analysis of the hopelessness of the situation also emphasizes Turkey's knowledge of the window of opportunity, caused partly by the passivity of its allies and the inability of the world (neutral and hostile nations), which provided them with an opportunity to implement their "final solution." Anckarsvärd's report described the basic need of a humanitarian intervention, but neither the friendly state (Germany) nor other major powers capable of implementing such an intervention were in a position to interfere to stop the genocide.

Soon after, on 15 July 1915, Anckarsvärd informed Stockholm of the warning delivered to the Porte by the German Ambassador about the Armenian massacres. "Turkey risked, especially among the neutral nations and foremost in America, evoking an extremely disadvantageous opinion. Furthermore, the unlawfulness and 
excesses of the Turkish government agencies opened the door for Europe's intervention and its interference in Turkey's internal affairs as soon as the war ceased." 31 The issue of a humanitarian intervention was made clear, but it also established the fact that such an action would, due to the prevailing circumstances, almost certainly come too late to save the Armenians.

Anckarsvärd's 15 July 1915 report stated that the "Armenian Patriarch has asked the Justice and Culture Minister, whether his intention is to annihilate the entire Armenian nation, in which case he was ready to start a movement to organize a mass emigration to, among other places, countries in South America. In this way, the Turks would get rid of the Armenians and the Armenians would suffer somewhat less than now." 32 This suggestion was quite similar to the Nazi's Madagascar plan. ${ }^{33}$

On 22 July 1915, Anckarsvärd informed his foreign ministry that it was not only the Armenians who were subject to persecutions, but also the Greeks who faced the same fate. The Greek chargé d'affaires in Constantinople, Mr. Tsamados, explained that: "it [the deportations] cannot be any other issue other than an annihilation war against the Greek nation in Turkey, and the measures therefore being taken are that the Turks have been implementing forced conversions to Islam; the obvious aim being that, if at the end of the war there would again be a question of European intervention for the protection of the Christians, there would be as few of them left as possible." 34

On 18 August 1915, the Swedish Ambassador notified Stockholm about a new German protest against the ongoing massacres. The German Ambassador's note contained a "much more serious tone," pointing out that Germany could not passively witness "how Turkey, through the Armenian persecutions, was going downhill, morally and economically. Furthermore, they [the Germans] protested against the Porte's course of actions, based on which her [i.e., Turkey's] ally Germany becomes suspected of approving these actions and, finally, Germany renounces any responsibility for the consequences." 35 On 2 September 1915, Anckarsvärd dispatched a new report stating that it "is obvious that the Turks are taking the opportunity to, now during the war, annihilate [utplåna] the Armenian nation so that when peace comes, the Armenian question no longer exists ... It is noteworthy that the persecutions of Armenians have been done at the instigation of the Turkish government and are primarily not a spontaneous eruption of Turkish fanaticism, even though this fanaticism is used and plays a role. The tendency to ensure that Turkey is inhabited only by Turks could, in due time, appear in a horrifying manner toward the Greeks and other Christians also." 36 Anckarsvärd made it quite clear that the massacres were neither an act of vengeance, nor a matter of civil or domestic war, but a systematic killing planned and implemented by the state, that is, a genocide. Thus, Turkey was behaving as a failed state, in which the structure and the norms for safeguarding the human rights of its citizens were suspended or ignored. ${ }^{37}$

The dispatch of 4 September 1915 presented the estimation of the Armenian losses given by the Armenian Patriarch. Anckarsvärd confirmed the Patriarch's estimation that approximately half the Armenian population had been erased, but doubted that the Armenian population was as numerous as 2 million, which the Patriarch asserted. Anckarsvärd also noted the negative economic impact these persecutions had in Turkey, since almost $80 \%$ of the trade was in Armenian hands. ${ }^{38}$

On 4 October 1915, SvM claimed that the US ambassador in Constantinople, Henry Morgenthau, had been ordered by his government to deliver a warning to the Turkish foreign minister, stating that "if the Armenian massacres do not cease, the friendly relations with the US will be jeopardized." 39 However, a similar directive 
was never issued by Stockholm. Instead of exhorted protests, the Swedish press now started to question the credibility of the news, citing the Turkish government's explanation that the measures were necessary because of the Armenian's liaisons with the Russians, British, and the French. ${ }^{40}$ Nevertheless, 1915 was replete with notes and reports about the state-implemented annihilation and extermination of the Armenian nation. The ambassador alone dispatched over ten reports about the persecution of the Armenians and their fate.

On 15 January 1916, Anckarsvärd dispatched a report written by the Swedish Military Attaché Wirsén, in which the situation of the military operations in Turkey was described. Commenting on the shortage of food, the report pointed out that this was partly as a result of bad harvests in Anatolia. The bad harvests were due to lack of labor since "so many men had been enlisted and in large areas, the most able-bodied population, i.e. the Armenians, have been subjected to the saddest fate ..."41 On 13 March 1916, Wirsén noted the tension surrounding the German officers, which was affecting their relations with the Turks. He assumed that something was about to happen at the Caucasian front, but the outcome was uncertain. He concluded the paragraph with the following sentence: "One can observe that the persecution of the Armenians has now begun in Thrace and even in Constantinople itself, when the Armenians living in the eastern parts of the city have begun being transported away to Asia." 42 Commenting on the general situation in May, Wirsén points out the main source for the epidemics spreading in the eastern front: "The health situation in Iraq is horrifying. Typhus fever claims numerous victims. The Armenian persecutions have to a large degree contributed to the spreading of the disease, since the expelled [Armenians] in hundreds of thousands have died from hunger and deprivation along the roads." 43

In his dispatch, dated 20 May 1916, Ambassador Anckarsvärd reported on the ongoing negotiations between Turkey and Germany, commenting on the situation in Turkey and the rumors of a possible surrender. Talking about the possible assaults on foreigners in Turkey and the subsequent foreign intervention, Anckarsvärd asserts that a foreign intervention would only weaken the Turkish Empire, but his analysis leaves no other option:

It is only due to the war that an ultra terrorist regime such as the present can be upheld. The true nature of this regime has come to the surface in such a significant manner through the Armenian persecutions. That the same violent methods are still implemented is evident through the recent intelligence reports regarding measures for subjugating agitation among Arabs ... In Aleppo there are rumors regarding an imminent deportation of the Arabs in hundreds of thousands. Such is the Young Turk administration, so incompetent is it in solving the difficult problems posed by the heterogeneous elements that the population is composed of. The military successes, thanks to German aid, should not create the illusion that Turkey will be re-born thanks to the war. The stub is so corroded that a real regeneration is inconceivable. ${ }^{44}$

Thus, Anckarsvärd predicted that, even though an intervention might not be the perfect answer, it might be the only alternative since no change would come from within to improve the situation of the minorities. However, the war gave the perfect opportunity to act as a failed state without fearing external interference.

On 7 June 1916, Dagens Nyheter reported that in Trabizond, for every 10,000 Armenian inhabitants, only 92 were still alive. "The extermination of the Armenians has been done systematically." 45 The Swedish passivity in response to the reported 
atrocities was criticized by editor G.H. von Kock, who not only criticized the government but also the church: "It is with sorrow one notes that, since the initial notification of the issue, nothing or at least very little has been done to assist the Christian Armenians and Syrians who in Asia Minor have been murdered in the hundreds of thousands by Turks and Kurds ... Sometimes it feels that we, here in Sweden, have been paralyzed in the face of all misery that now prevails and increases constantly in the world." 46

Almost a month later, Anckarsvärd dispatched a report notifying Stockholm of the possibility of a Greek declaration of war against Turkey, which could result in the repetition of the Armenian fate, this time engulfing the Greeks in Turkey. The report is significant due to the expected request for protection of Greek interests in Turkey: "[T]he Dutch Ambassador here has notified his government, that in case of a possible request from Greece regarding entrusting the protection of its interests in Turkey to the Dutch legation, it must be denied. The Foreign Ministry in [The] Hague has replied that it completely approves the Ambassador's view. On my own behalf, I would like respectfully make the same proposal to Your Excellency as it concerns this embassy, in case the government in Athens would turn to $\mathrm{H}$ [is] M[ajesty]'s government." 47 This is the only instance where Anckarsvärd recommended a certain policy to Stockholm regarding the events in Turkey. It also illustrates how the fear of endangering one's own country's interests could directly prevent that country from intervening in case of a humanitarian urgency. This policy would become much more obvious once the new Swedish ambassador arrived in 1920.

In his dispatch on 5 January 1917, Anckarsvärd made an important observation of the German influence in Turkey in regard to the impending risk of Turkish surrender: "The situation would have been different if Turkey had followed the advice of the Central Powers in letting them organise the question of provisioning etc.... Even worse than this is, however, the extermination [utrotandet] of Armenians, which, perhaps, could have been prevented if German advisers had in time received authority over the civilian administration as the German officers actually practise over army and navy ... The above-mentioned statements, as mentioned, come from a diplomatic official allied with Turkey. Your Excellency can then consider what the neutral diplomats think of the situation here."48

On 14 January 1917, Anckarsvärd sent a dispatch regarding the decision to deport the Ottoman Greeks. He noted that the US ambassador had been trying to stop the deportation by stressing to the Porte the kind of impression "a repetition of the Armenian persecutions, but this time against the Greeks, would give in the entire civilised world." He ended the report by asserting the following: "What above all appears as an unnecessary cruelty is that the deportation is not limited to the men alone, but is extended likewise to women and children. This is supposedly done in order to much more easily confiscate the property of the deported." 49

The Armenian question was revived in 1917 in Sweden. Then, even writers and politicians joined the debate. The Turkish embassy in Stockholm got engaged in the debate, refuting the allegations presented in the Swedish press. On March 24, Dagens Nyheter published the parliamentary interpellation, written by Stockholm's Mayor Carl Lindhagen to Foreign Minister Johannes Hellner, stating, "Earlier cruelties in Armenia fade in the face of the actual extermination [utrotandet] of the Armenians, which recently has been going on." He continued, asking whether "the government, alone or in cooperation with other neutral governments, who could 
have any influence in the matter, wish to help the right of the Armenian population to protect their lives, their property and their nationality?"50

As an answer to Mayor Lindhagen's interpellation to the Swedish foreign minister, Chairman of the Conservative Parliamentary Group Arvid Lindman rejected any claim for intervention, referring to the fact that Sweden will not interfere in other state's internal affairs. ${ }^{51}$ The leader of the opposition, Chairman of the Social Democratic Party Hjalmar Branting, mentioned that Sweden should protest against the Armenian massacres in the same way Sweden protested against the "catastrophe in Belgium." 52 However, no protest was ever issued. On March 26, a protest meeting was arranged in support of the Armenians. In a packed auditorium in Stockholm, the meeting was presided over by Mayor Lindhagen, and Hjalmar Branting gave the introductory speech. The keynote speech was delivered by the author Marika Stjernstedt. The French, Russian, Belgian, and Italian ambassadors also attended the meeting and funds were raised. ${ }^{53}$ Talking about the Armenian massacres during the last decades of nineteenth century, Branting rebuked the conservative newspapers for having practically silenced the information on the massacres, stating that the world had "witnessed that in Armenia, a fully organized genocide [folkmord] has been carried out and the events down there are unparalleled with all that which has happened during the war." 54 Branting might very well have been the first public figure who, decades before Raphael Lemkin, used the term folkmord, that is genocide, in regard to the annihilation of a nation. Branting also informed the audience that he, back in 1916, had contacted the then foreign minister Knut Wallenberg to make him intervene and put a stop to the massacres. The courting had been fruitless. ${ }^{55}$ It should be borne in mind that at this point in time, Branting was the opposition leader, chastising the government for its Germanophile attitudes and indifference in the face of an obvious humanitarian disaster. He would have the chance to address the issue when he became prime minister, which I will touch upon later. The meeting infuriated the Turkish mission in Stockholm, which published an article in SvM explaining that the Turkish government, at the beginning of the war, had cautioned all that there would be "severe punishment for attempts of rebellion. Armenians continued with their old policy, and a bloodbath and attacks on Turks began-in other words, all symptoms for a total insurrection." 56 Nine days later, Stjernstedt published a passionate article about the Armenian massacres, citing new testimonies verifying the accusations against the Turks. ${ }^{57}$

In a 20 August 1917 report about the impact of the war on Turkey, the territorial losses, as well as the impact on the society, the Swedish Envoy Ahlgren identifies the following causes for increased living costs: "obstacles for domestic trade, the almost total paralyzing of the foreign trade, and finally the strong decreasing of labor power, caused partly by the mobilization but also by the extermination of the Armenian race [utrotandet af den armeniska rasen]."58 Thus, Ahlgren concurred with Anckarsvärd's view when describing the true goal of the massacres and the nature of the Armenian fate. The analysis of the situation was elaborated in more detail soon after in the report about the new masters of Turkey, the "Young Turks." In a dispatch on 10 September 1917, Ahlgren gives a detailed description of the Union and Progress Party. The Turkish policy prior to the war was that of "Ottomanism," aiming to homogenize the disintegrating heterogenic empire that until then was kept together by autocracy. However, the new leaders realized that Ottomanism threatened the Turkish element, since other subdued people "demanded equal rights for themselves as the Turks: security for life and property, access to the civil and the military 
offices, yes, even to government." 59 In order to prevent this, Talaat and Enver, through the coup d'état in 1913, eliminated the liberal government, and started implementing changes in the constitution for improving the rights of the Turkish element. Referring to the new Turkish leader's policy of homogenizing Turkey, Ahlgren asserts that this was being planned by "assimilating other nationalities and, when it failed, soon enough through political persecutions and extermination. It is in the light of these facts that one should regard the measures taken against the Armenians and maybe future similar [actions] against the Greeks." 60 All opposition had been brutally removed, all major positions within the administration were appointed to loyal people, and a new police force was created to act as a secure tool in the government's hand. The same applied to the army. ${ }^{61}$ The government was in full control over the country.

In 1918, after a conversation with Turkish Foreign Minister Nessimy Bey, Anckarsvärd sent a letter to Stockholm, dated 22 April, reporting on the information he had received from the minister. Nessimy Bey had refuted the recent news about renewed Armenian massacres, calling them British propaganda and had pointed out that their previous sufferings were due to the Armenians' own rebellious posture and the subsequent evacuation. "But," Anckarsvärd added, "to just recently [and] unnecessary subject the Armenians to new sufferings could not be comprehended by any reasonable person in Turkey, since this would further nourish the already prevailing indignation toward Turkey." 62 In other words, Anckarsvärd hinted at existing foreign resentment towards Turkey and its treatment of the Armenian subjects, even though a strong condemnation of the actions was conspicuous by its absence. On 25 August, Ahlgren reported on the ongoing peace negotiations in Caucasus between Turkey and the newly created Caucasian republics of Georgia, Azerbaijan, and Armenia. Mentioning the Turkish push eastward, into Caucasus towards Baku and beyond, he notes that the territorial demands of the Georgian and Azerbaijani republics were mostly met by Turkey, while the original Armenian claims to a territory of 45,000 square kilometers were limited to only 11,000 square kilometers, largely encompassing the Erivan province. "Thus, Armenia was heavily circumscribed, but this is less surprising than that the Turks have, at all, decided to recognize an independent Armenian state, which conspicuously contradicts their implemented policy since 1915, which strove to solve the Armenian question by the extermination of the Armenian race [den armeniska rasens utrotande]." 63 However, Ahlgren noted that the Turkish recognition was not voluntary, but due to German persuasion. Nevertheless, the Turkish offensive towards Baku was halted by the signing of the armistice at Mudros, by which Turkey surrendered on 30 October 1918. ${ }^{64}$ The Turkish reconciliation measures would continue in 1919.

It is noteworthy to mention a dispatch that Anckarsvärd sent to Stockholm on 8 October 1918. The dispatch contained a debriefing on Anckarsvärd's audience at Crown Prince Abdul Medjid's court. The prince had dismissed the Talaat cabinet due to its misrule of the country and especially lost confidence, internally as well as externally, due to "two unforgivable errors, which in the eyes of Turkey and abroad, made them unsuitable for running the country, namely partly the Armenian persecutions, and partly the exaggerated cruelties committed in Syria against the conspiracyentangled Arab sheiks."65 There are two important notes in this dispatch: (1) the Turkish rule indicated a failed state, misgoverning the country in general and not only in regard to the minorities; (2) the Turkish reaction, here by the Crown Prince, admitted to the knowledge of the atrocities long before the Entente powers exerted pressure on defeated Turkey and subsequent trials. 
On 10 January 1919, Anckarsvärd reported on the future prospects of Turkey. A major issue mentioned in the report was the future of Cilicia (and also Diarbekir), whether the important and rich province would be included in the planned independent Armenia, or left to Turkey. This report was one of the first of many from Constantinople to Stockholm, indicating the impact of the creation of Armenia and the affected Turkish finances. The main issue was how to salvage Turkey from an impending financial catastrophe, and more importantly, how to save foreign capital invested in Turkey. Anckarsvärd notes that a French adviser, commenting on the financial situation in Turkey, advises that "Turkey must be saved from bankruptcy and at the same time save the considerable French and English capital here in Turkey. 'The Entente' should, in its own interest, not ruin Turkey, which they hope, in the future, to fully be able to control and exploit freely." 66 Anckarsvärd concludes: "The cliché states that one does not ruin one's debtor, and the question is, whether one should best draw conclusions from this thesis." Future reports, mentioned later, will further illuminate the implementation of this thesis by the foreign powers in regard to Armenia and Turkey.

Until this point, the embassy dispatches clearly stated that there were largescale massacres with the aim of annihilating the Armenian nation. There had been some Armenian revolutionary activities, partly due to the Turkish atrocities committed in the past, but the scale of these and other actions were hardly reason to exterminate the entire Armenian nation. Furthermore, the dispatches pointed out, on more than one occasion, that the Armenian massacres were not a result of spontaneous public actions, but government orchestrated implementation of erasing a nation. Thus, it is safe to say that the Swedish government's policies, irrespective of the additional information provided by domestic newspapers and missionaries, were, based solely on dispatches from its foreign and military missions, well informed of the ongoing eradication of the Armenian nation.

However in 1920, with the arrival of a new Swedish envoy to Constantinople, the tone of the reports and analysis changed dramatically, at least in regard to Armenians and the Armenian question. The new envoy was Gustaf Oskar Wallenberg, former Swedish envoy to Japan, and half-brother to K.A. Wallenberg, the former Swedish foreign minister. He represented a completely new breed of diplomats in the Swedish Foreign Office. He differed from the traditional Swedish diplomats in several ways: He was no career diplomat, but rather a businessman, a fact that can definitely be ascribed to his family background. He belonged to the wealthy Wallenberg clan, by far Sweden's family of financial leaders. However, despite his plutocratic background, he was not from an aristocratic family, which was the case for Swedish diplomats normally. ${ }^{67}$ Furthermore, he was an energetic advocate for Swedish trade interests, both in existing markets, and especially in new emerging ones. ${ }^{68}$ The latter aspect is quite evident in the studied material as well. While Wallenberg's predecessor, Anckarsvärd, primarily reported on the military and diplomatic issues, Wallenberg's reports are replete with comments on trade possibilities, strategies for expansion of Swedish export to the region, etc.

On 26 January 1920, the Swedish Foreign Ministry sent a letter marked "Strictly Confidential" [Strängt Förtroligt] to its ambassadors in Oslo, Helsinki, Berlin, Vienna, The Hague, Bern, Rome, and London, as well as to Lieutenant Colonel Francke at the General Staff's headquarters. The attachment to the letter is an anonymous report from "a Swede, who has been staying in Constantinople for a long time."69 The report in question completely refutes the massacres: "The 
talk about massacres of the 'Christians' and so on is undoubtedly absolutely untrustworthy; it is characteristic that there are no offered verifiable details, 'the national forces' are presented only in general as massacrers, but does anyone ask for proof?"70 The dispatch statement asserts that the news is due to the "irresponsible agitation against Turkey, which, since the truce, has been allowed to be carried out by more or less loathsome Levantine elements ..."71 There is no clarification in regard to these "Levantine elements," even though one could assume the nationalities-Armenian and Greek-that the author has in mind.

On 12 April 1920, the Swedish Embassy sent a dispatch entitled "regarding the future position of Armenia," asking Stockholm about the League Council's decision to find a "civilized state that wished to accept the responsibility of mandate [power] over Armenia under the supervision of the League of Nations." "72 During a conversation, M.J. Gout, Chief of French Affairs in the League of Nations, had told the Swedish envoy that "it would be extremely desirable if one or several states, who might be inclined to accept this significantly important and humanitarian task ..." The embassy concluded the message by offering further information if Stockholm was to be inclined to accept the offer. ${ }^{73}$ On 24 April, a telegram was received in Stockholm, referring to newspapers claiming that either Holland, Sweden, or Norway intended to take the mandate role. In any case, the USA would assume the responsibility for the economic aid. According to additional information, the final decision was postponed, awaiting the statement of the International Commission. ${ }^{74}$

On 26 April 1920, however, G.O. Wallenberg dispatched a three-page recommendation to Foreign Minister Erik Palmstierna, in which he pointed out the importance of dropping any support for the Armenian cause for the sake of Swedish interests in Turkey and the region. He went quite far in justifying his point of view by, among other things, asserting that the "Armenian national character is highly unreliable, something which, by the way, is nothing to be surprised about a people, whose policy for centuries has been restricted to the fields of intrigue ... The representatives of the mandate power there will risk being used for aims that they will not like; and if there be any scandals, the Armenians will always let them bear the responsibility." 75

The content of the report can only be seen as a clear attempt to downplay the need for Swedish involvement based on moral and humanitarian issues. Wallenberg approached the problem from a purely realistic perspective, safekeeping Swedish economic and political interests. Armenia, unlike its neighbors, had nothing to offer Sweden. Wallenberg made this utterly clear and would continue this rhetoric in order to diminish the Armenian position in the equation. It is especially worth noting that his analysis and observations strongly contradict both his predecessor's views and those of Wirsén. Wallenberg was a businessman, interested in profits, not in humanitarian responsibilities. During the subsequent years, Wallenberg continued his negative attitude toward the Armenians and the Armenian question. He dismissed the claims that there were any Armenians in Turkey whatsoever, but there were "Turks of Christian faith." To verify that there was no Armenian community in Turkey, Wallenberg cites an Armenian lawyer who said: "We are Turks and wish to remain that way."76 Later Wallenberg asserts that the Armenians do not have a future anyway. In Turkey, practically all "so-called Armenians speak Turkish," and "in the Soviet Union, they will surely be Russified."77 Furthermore, he claimed that the effort to create an independent Armenia was entirely a desire of diasporic Armenians, who were "rootless nationalists," and had no anchorage whatsoever among Armenians in Armenia. In this regard he compared the Armenian 
exile organizations with the Zionist movement, comparing the Turkish Armenians to the Palestinian Jews, criticizing their co-nationalists in the diaspora. ${ }^{78}$

On 22 October 1920, news was received about Armenia's request for Entente assistance due to an ultimatum from Soviet Russia. Citing Indépendance Belge, Dagens Nyheter reported that "the League of Nations, in regard to Armenia, has proposed that the Supreme Council should appoint a mandate power for Armenia."79 The issue of a Swedish mandate over Armenia was brought up during the autumn session of the League of Nations. On 20 November 1921, the League had its first General Assembly, with Hjalmar Branting as the leader of the Swedish delegation. The meeting had received numerous telegrams from Armenian organizations in France, Turkey, Romania, USA, and Egypt, among other places, appealing to the members of the League to save Armenia. ${ }^{80}$ In terms of the Grotian definition, these appeals were the calls from the suppressed subjects asking for foreign intervention as a refined form of "just war." 81 Referring to the telegrams and the appeal of the Armenians, the Yugoslavian delegate asked the major powers to intervene. The humanitarian intervention was not only a rescue mission, but also a peacekeeping one. Thereafter, Branting took the podium, seconding the previous speakers, demanding that the major powers intervene in the matter. ${ }^{82}$ Thus, one could conclude that, in Branting's view, the intervention was not only a moral duty for protecting the human rights and the security of the Armenian subjects in Turkey, but also that the whole situation posed a threat to international security and the newly established League of Nations. Both France and England declined the mandate, referring to the fact that they already had accepted mandate missions. Upon receiving the news, Swedish Prime Minister Louis De Geer the Younger immediately telegrammed back to the League, declining the mandate over Armenia, due to "the distance between the countries, and the complex and grave nature of the Armenian problem." 83 Norway's telegram was, literally, a carbon copy of the Swedish reply, while the Danish answer was also the same in its content. ${ }^{84}$

On November 23, Nya Dagligt Allehanda published an article posing the following question: "Shall the Armenian question lead to the creation of an international police force?" 85 This also might be the very first occasion when the need of an international peacekeeping force had arisen. That the League was unwilling or unable to make any commitment in regard to the Armenian question in the hour of need was exposed by the Social-Demokraten correspondent in Geneva, who wrote, "The civilized nations looked at each other, a bit ashamed indeed and each and everyone whispered their answer to the Council: 'Surely Armenia must be aided. It is a responsibility toward all humanity to aid Armenia. It must not happen that Armenia is not aided. But why should I do it? Why should I? Why should I?' was sounded from every direction. 'Why exactly should I expose myself for the risk and the inconvenience of putting my nose in this robber's den?' And so all the civilized nations there stood on the shore, around the drowning people, each and everyone with its lifeline in hand. But no one wanted or dared to throw it, fearing they would themselves be drawn into the water." 86 The world community obviously saw the problem and expressed its sympathy, but that was all. Armenia was simply not worth the risk. Whoever engaged in accepting mandate power over Armenia would risk both being burdened with expenses and getting involved in conflict with the economically and politically more adept neighbors such as Turkey, Azerbaijan, and Russia. The responses from almost all countries declining participation, who acknowledged the need for humanitarian intervention, illustrates that while there 
is sufficient will to intervene, there is insufficient will to devote resources to the cause.

On 19 October 1921, Wallenberg wrote yet another letter in regard to the possible request by the League of Nations for Sweden to act as guarantor for a temporary Armenian government in Cilicia. The prospects for such a request looked quite slim, but nonetheless, Wallenberg's recommendation, based on the same reasons he had provided about the suggestion concerning the mandate power, was to decline such a request. ${ }^{87}$ Commenting on the issue of non-interference in a sovereign state's internal affairs, he notes that "to seek to make an international issue of this would, at its core, be the same as choosing to raise the principle that states would no longer legally have the right to take measures against plots regarding their security." 88 On 15 November 1921, the economic worth of a close relation with Constantinople was made more clear when Wallenberg dispatched a four-page report analyzing the development in the Black Sea region, in which he repeatedly emphasized the renewed importance of Constantinople, pointing out (mentioned twice and underlined on pages 1 and 4) that "the road to the new Russian market does not pass over the Baltic Sea any more, but over Constantinople and the Black Sea ports." 89 Swedish trade and economic interests in Turkey were far more important than any humanitarian-related problem.

\section{Conclusion}

Taking the data at hand into consideration, it is clear that the information regarding the massacres in the Ottoman Empire and their genocidal nature was abundant in Swedish newspapers as well as in the reports submitted to the Church of Sweden, the Swedish Defense Ministry, and the Swedish foreign ministry and government. It is safe to assert that the Swedish government had a clear view of what transpired in Western Armenia during the Great War. Even if one were to disregard the information presented by the missionaries and the press, the Swedish Government, especially through its embassy in Constantinople, as well as through its military attaché in Turkey, was well informed about the ongoing annihilation. In his dispatches to Stockholm, Ambassador Anckarsvärd stressed the fact that what took place in the Ottoman Empire was neither an act of mutual killing, nor measures taken against Armenian insurrection, but a well-planned systematic annihilation of the Armenian nation, initiated and implemented by the Turkish government. Indeed, the reports tell of Armenian collaboration with the Russian Army and armed resistance in some places, and they also make clear that 1) the acts of vengeance occurred long after the bulk of the 1915-1916 massacres and deportations, thus the government's actions can not be justified as measures against insurgency and treason; 2) the cooperation with the enemy was to a very limited extent and could not justify the implemented annihilation of the entire Armenian nation. This view was further verified by the information and testimonies published by the Swedish, as well as Danish, Norwegian, German, and American missionaries and relief workers who had returned home during the last years of the war. The reports also indicate that the Turkish government relied on the fact that, as long as the war was going on, the world would be unable to intervene. By the time the war ended, the genocide had taken its toll, emptying Western Armenia of its Armenians. This, in part, legitimated claims that it was impossible to create an Armenia based on national self-determination, simply because there were no Armenians left to make this decision. The date of the first classified diplomatic intelligence indicates that 
Stockholm received an early warning and was notified of the ongoing humanitarian catastrophe during the first steps of the large-scale massacres and deportations. Later reports further indicated that Turkey's actions illustrated a state violating the rights and safekeeping of its citizens. That is to say, Turkey was a failed state, which in turn could justify a humanitarian intervention.

A limited number of politicians, such as Hjalmar Branting, appealed to the Swedish public to influence Swedish decision making, but there are no indications in the data studied that suggest any effect in this matter. It seems that only the missionaries took action and, where and when possible, did everything in their power to give shelter to the victims, actively worked to provide assistance and food for the deportees, and saved as many as possible from executions, etc. Ambassador Anckarsvärd, despite his clear knowledge of the situation, refrained from making any official recommendations to his government in regard to this issue, or to ask Stockholm about any possible directives. Having said that, one must be reminded that Anckarsvärd remarked on the moral aspects of the annihilation policy and that the Turkish government made itself guilty of committing crimes against humanity, but his diplomatic position and obedience to the neutrality policy did not allow him to act. Unlike Anckarsvärd, Wallenberg played an active role in Stockholm's decision making, or at least influencing the basis for it, by openly advocating a specific policy in regard to the Armenian question. Wirsén, too, had a comprehensive knowledge about the annihilation, but as a military envoy might not have had the authority to make political comments. Only later, when commenting on his experience from the mission, does Wirsén describe the massacres and the deportation of the Armenian nation and try to interpret their true nature and the aims of the Turkish leaders. As far as the Swedish government is concerned, there will need to be an extended study of the events in order to comment on the Swedish official action, or the lack thereof. There are no data indicating that Sweden would have put forward any protests or pressure for a humanitarian intervention. Nonetheless, the absence of relevant information does not allow a full interpretation of the official stand. Yet, later, when the question of a mandate power was brought up, Sweden acted like other nations, unwilling to be involved in the country so far away. Thus, the wording of the Swedish correspondent asking "Why should I?" depicts quite well the sentiment that prevailed in Sweden in regard to far-away Armenia.

Expanding the horizons of this study, and trying to find out how the Swedish officials debated the news received about the Armenian massacres, would enable one to investigate a new perspective on the data presented in this study. How does a small state respond when confronted with the news about an ongoing humanitarian crisis and the option of intervening? What alternatives did Stockholm have, how did the decision makers debate, and what did they decide? Do massive humanitarian crises, such as genocide, challenge the fundamental doctrine of small-state policies or that of an international organization, such as the UN? How can an effective humanitarian intervention be implemented in a time of a major regional or global conflict when the perpetrating side is already at war with the potential interveners? Is an intervention by foreign states always impossible when genocide is committed during the course of a global war? Are there any alternative solutions for a military intervention? In order to address these questions, additional factors must be added to the equation, such as the dynamics of Sweden's foreign policy of abandoning its strict neutrality by engaging in the League of Nations, but also the perceived imminent threat from the new Bolshevik Russia. 


\section{Notes}

1. This article is a short summary of a master's thesis and, due to space limitations, does not include the full scope of articles, documents, and reports in regard to the ongoing genocide in the Ottoman Empire. See Vahagn Avedian, "The Armenian Genocide 1915: From a Neutral Small State's Perspective," (MA thesis, Uppsala University, 2008; http://www.armenica.org/material).

2. Mariam Bakhtiari, Kalla det vad fan du vill (Stockholm: Ordfront, 2005), 9. In the Swedish text, "wogs" translates to "svartskalle," verbatim "black head," referring to the dark color of the foreigners, which contrasts to the light brown hair color of the native Swedes. Also see Tomas Hammar, Sverige åt svenskarna: Invandringspolitik, utlänningskontroll och asylrätt, 1900-1932 (Stockholm: Stockholm University, 1964), 69-71. Unless otherwise noted, all translations from non-English sources are my own.

3. One argument used by present-day Turkey to avoid recognition of the 1915 genocide refers to the alleged difference between "Ottoman" and "Turkey," asserting that Turkey did not exist before 1923, nor is the present state responsible for any actions committed by the Ottoman government. However, when studying the period in question, it becomes evident that this transformation from Ottoman to Turkey was already ongoing. Several foreign states, in their diplomatic letters, reports, and documents, use "Turkey" or "Ottoman Turkey" for designating the state. Thus, this article will use Turkey when referring to the Ottoman Empire. For further discussion, see Vahakn N. Dadrian, The Key Elements in the Turkish Denial of the Armenian Genocide: A Case Study of Distortion and Falsification (Toronto: Zoryan Institute, 1999), 5-6.

4. For further information see Vahakn N. Dadrian, "The Armenian Question and the Wartime Fate of the Armenians as Documented by the Officials of the Ottoman Empire's World War I Allies: Germany and Austro-Hungary," International Journal of Middle East Studies 34, no.1 (February 2002): 59-85; Vahakn N. Dadrian, The History of the Armenian Genocide: Ethnic Conflict from the Balkans to Anatolia to the Caucasus (Providence, RI: Berghahn, 2004). Also see W.J. van der Dussen, "The Question of Armenian Reforms in 1913-1914," The Armenian Genocide, Documentation, vol. 8 (München: Institut für Armenische Fragen, 1991).

5. Gunilla Lundström, Per Rydén, and Elisabeth Sandlund, Den svenska pressens historia, Det moderna Sveriges spegel (1897-1945), vol. 3 (Stockholm: Ekerlid, 2001), 124.

6. Tommy Hansson, Neutralitetsmyten: En granskning av svensk utrikespolitik (Stockholm: Contra, 1991), 20.

7. Erik Lönneroth, Den svenska utrikespolitikens historia (Stockholm: Norstedt, 1959), 27.

8. Maria Anholm, De dödsdömda folkens saga (Stockholm: Nordiska öresbibliotek, 1906); E. John Larson, Förföljelserna och blodbaden i Armenien : Särskild från år 1894 till år 1897 (Helsingborg: Missionsbokhandeln, 1897); Per Pehrsson, Armenierna och deras nöd (Stockholm, 1896).

9. Riksarkivet [National Archives] (RA), Swedish missionary letters regarding Armenia. For Alma Johansson's description of the Armenian Genocide, see Alma Johansson, Ett folk $i$ landsflykt: Ett år ur armeniernas historia (Stockholm: Kvinnliga Missions Arbetare, 1930).

10. Gustaf Hjalmar Pravitz, Från Persien i stiltje och storm (Stockholm: Dahlberg, 1918).

11. Nya Dagligt Allehanda's German affiliation would bloom into full sympathy for National Socialism during the 1930s.

12. Pravitz, Från Persien $i$ stiltje och storm, 222.

13. Nya Dagligt Allehanda (Stockholm), 23 April 1917.

14. Pravitz, Från Persien i stiltje och storm, 221.

15. Ibid., 22, 226-27.

16. Ibid., 219, 221-23.

17. By a coincidence, Wirsén is the same Swedish military officer who was appointed as chairman for the commission that the League of Nations put in charge of arbitration in the Mosul Crisis. It was Wirsén's detailed knowledge of the region, his experiences from 
the war, and his familiarity with the existing situation that made him an important asset in the commission appointed to resolve the crisis.

18. Carl Einar af Wirsén, Minnen från fred och krig (Stockholm: Bonnier, 1942), 132.

19. Ibid., 133.

20. Ibid., 220-26. Also see 120, 288, and 294.

21. Ibid., 223.

22. Ibid., 223.

23. Ibid., 226. This view is confirmed by Dadrian as well. See Dadrian, The History of the Armenian Genocide: Ethnic Conflict from the Balkans to Anatolia to the Caucasus, 289, 384-85.

24. Wirsén, Minnen från fred och krig, 226.

25. Riksarkivet, Utrikesdepartementet (Foreign Dept.), 1902 års dossiersystem, vol. 1148, No. 99 (30 April 1915), 3.

26. The Sublime Porte refers to the gate of the Ottoman Imperial Government, more specifically the Foreign Ministry.

27. Riksarkivet, Utrikesdepartementet, vol. 1148, No. 99 (30 April 1915), 5.

28. Svenska Morgonbladet (Stockholm), 26 May 1915.

29. Riksarkivet, Utrikesdepartementet, vol. 1148, No. 137 (6 July 1915).

30. The Committee of Union and Progress ("Ittihad ve Terakki Cemiyeti" in Turkish) was the central leadership for the movement known in the West as the Young Turks.

31. Riksarkivet, Utrikesdepartementet, vol. 1148, No. 142 (14 July 1915).

32. Riksarkivet, Utrikesdepartementet, vol. 1148, No. 145 (15 July 1915).

33. For the Madagascar Plan, see Christopher R. Browning, The Origins of the Final Solution: The Evolution of Nazi Jewish Policy, September 1939-March 1942 (London: Heinemann, 2004), 81-83.

34. Riksarkivet, Utrikesdepartementet, vol. 1148, No. 155 (22 July 1915).

35. Riksarkivet, Utrikesdepartementet, vol. 1148, No. 170 (18 August 1915).

36. Riksarkivet, Utrikesdepartementet, vol. 1148, No. 182 (2 September 1915).

37. Barbara von Tigerstrom, Human Security and International Law: Prospects and Problems (Oxford: Hart Publishing, 2007), 96, 102-103. Also see Catherine Lu, "Whose Principles? Whose Institutions? Legitimacy Challenges for 'Humanitarian Intervention,'” in Humanitarian Intervention, ed. Terry Nardin and Melissa S. Williams (New York: New York University Press, 2006), 197; Thomas G. Weiss, Humanitarian Intervention: Ideas in Action (Cambridge: Polity Press, 2007), 18.

38. Riksarkivet, Utrikesdepartementet, vol. 1148, No. 183 (4 September 1915).

39. Svenska Morgonbladet, 4 October 1915.

40. Svenska Morgonbladet, 11 October 1915.

41. Riksarkivet, Utrikesdepartementet, 1902 års dossiersystem, vol. 1149a, No. 20 (15 January 1916).

42. Krigsarkivet (War Archives), Generalstaben, Letter 13, (13 March 1916).

43. Krigsarkivet, Generalstaben, Letter 8 (13 May 1916).

44. Riksarkivet, Utrikesdepartementet, vol. 1149a, No. 80 (20 May 1916).

45. Dagens Nyheter (Stockholm), 7 June 1916.

46. Dagens Nyheter, 30 August 1916.

47. Riksarkivet, Utrikesdepartementet, vol. 1149a, No. 137 (25 September 1916).

48. Riksarkivet, Utrikesdepartementet, vol. 1149a, No. 9 (5 January 1917).

49. Riksarkivet, Utrikesdepartementet, vol. 1149a, No. 14 (14 January 1917).

50. Dagens Nyheter, 24 March 1917.

51. Riksdagens arkiv, Andra kammaren, Interpellationer (The Second Chamber of the Riksdag, Interpellations) 35:29-30 and 62:7-8 (23 March 1917).

52. Riksdagens arkiv, Andra kammaren, Interpellationer, $62: 10$ (23 March 1917).

53. Svenska Morgonbladet, 28 March 1917.

54. Social-Demokraten (Stockholm) (27 March 1917); Svenska Dagbladet, 28 March 1917.

55. Social-Demokraten, 27 March 1917. 
56. Svenska Morgonbladet, 2 April 1917.

57. Dagens Nyheter, 11 April, 1917.

58. Riksarkivet, Utrikesdepartementet, vol. 1149b, No. 232 (20 August, 1917).

59. Riksarkivet, Utrikesdepartementet, vol. 1149b, No. 260 (10 September 1917).

60. Ibid.

61. Ibid.

62. Riksarkivet, Utrikesdepartementet, vol. 1149b, No. 58 (22 April 1918).

63. Riksarkivet, Utrikesdepartementet, vol. 1150, No. 118 (25 August 1918).

64. Hrant Pasdermadjian, Histoire de l'Arménie depuis les origines jusqu'au traité de Lausanne, (Paris: Librairie orientale, 1949), 494.

65. Riksarkivet, Utrikesdepartementet, vol. 1150, No. 143 (8 October 1918).

66. Riksarkivet, Utrikesdepartementet, vol. 1150, No. 5 (10 January 1919).

67. Bert Edström, Storsvensken $i$ yttersta östern: G.O. Wallenberg som svenskt sändebud $i$ Japan, 1906-1918 (Stockholm: University Center for Pacific Asia Studies, 1999), 6.

68. Ibid., 13-16.

69. Riksarkivet, Utrikesdepartementet, 1920 års dossiersystem, vol. HP 1474, No. 55 (26 January 1920).

70. Riksarkivet, Utrikesdepartementet, vol. HP 1474, No. 55 (26 January, 1920).

71. Ibid.

72. Riksarkivet, Utrikesdepartementet, vol. HP 1474, No. 160 (12 April 1920).

73. Ibid.

74. Riksarkivet, Utrikesdepartementet, vol. HP 904, Telegram, Paris 0305/23 40W 2318 40, Cabinet Stockholm (24 April 1920).

75. Riksarkivet, Utrikesdepartementet, vol. HP 1474, No. 74 (26 April 1920).

76. Riksarkivet, Utrikesdepartementet, vol. HP 1474, No. 69 (17 March, 1921).

77. Ibid.

78. Ibid. Richard Hovannisian's excellent and descriptive work, Armenia on the Road to Independence, 1918, however, gives a very different image than that depicted by Wallenberg. See Richard G. Hovannisian, Armenia on the Road to Independence (Berkeley: University of California Press, 1967).

79. Dagens Nyheter, 22 October 1920.

80. Göran Gunner and Erik Lindberg, eds., Längtan till Ararat, En bok om Armenien och armenisk identitet (Göteborg: Gothia, 1985), 273.

81. For the "Grotian Doctrine" on international politics and responsibility, and humanitarian intervention in particular, see John G. Heidenrich, How to Prevent Genocide: A Guide for Policymakers, Scholars, and the Concerned Citizen (Westport, CT: Praeger, 2001), 135. See also Kok-Chor Tan, "The Duty to Protect," in Humanitarian Intervention, ed. Terry Nardin and Melissa S. Williams, 84-116 (New York: New York University Press, 2006), 89.

82. League of Nations, Assembly Protocol (22 November 1920), 187.

83. League of Nations, Official Journal, no. 8 (November-December 1920), 96.

84. Ibid., 96-97.

85. Nya Dagligt Allehanda, 23 November, 1920.

86. Written on November 24 and published in Social-Demokraten, 29 November 1920.

87. Riksarkivet, Utrikesdepartementet, vol. HP 1474, No. 234 (19 October 1921).

88. Ibid.

89. Riksarkivet, Utrikesdepartementet, vol. HP 566B, No. 267 (15 November 1921). 